Article

\title{
Five Italian Families with Two Mutations in BRCA Genes
}

\author{
Maria Teresa Vietri 1,2,*, Gemma Caliendo ${ }^{2}$, Giovanna D'Elia ${ }^{2}$, Marianna Resse ${ }^{1,2}$, \\ Amelia Casamassimi ${ }^{1}$ (D), Pellegrino Biagio Minucci ${ }^{1,2}$, Concetta Dello Ioio ${ }^{3}$, Michele Cioffi ${ }^{1,2}$ \\ and Anna Maria Molinari 1,2 \\ 1 Department of Precision Medicine, University of Campania “Luigi Vanvitelli”, Via L. De Crecchio, \\ 80138 Naples, Italy; marianna.resse@unicampania.it (M.R.); amelia.casamassimi@unicampania.it (A.C.); \\ pellegrinob.minucci@unicampania.it (P.B.M.); michele.cioffi@unicampania.it (M.C.); \\ annamaria.molinari@unicampania.it (A.M.M.) \\ 2 Unity of Clinical and Molecular Pathology, University of Campania "Luigi Vanvitelli", 80138 Naples, Italy; \\ gemma.caliendo@unicampania.it (G.C.); giovanna.delia@policliniconapoli.it (G.D.) \\ 3 Oncology Unit, Hospital “Andrea Tortora,” ASL Salerno, 84016 Pagani, Italy; c.delloioio@aslsalerno.it \\ * Correspondence: mariateresa.vietri@unicampania.it; Tel.: +39-081-566-7639; Fax: +39-081-450-169
}

Received: 12 November 2020; Accepted: 1 December 2020; Published: 3 December 2020

\begin{abstract}
Double heterozygosity (DH) in BRCA1 and BRCA2 genes and double mutation (DM) in $B R C A 1$ or $B R C A 2$ are extremely rare events in the general population, and few cases have been reported worldwide so far. Here, we describe five probands, all women, with breast and/or ovarian cancer and their families. Particularly, we identified two probands with $\mathrm{DH}$ in the BRCA1/2 genes with a frequency of $0.3 \%$ and three probands with DM in the BRCA2 gene with a frequency of $0.5 \%$. The DH BRCA1 c.547+2T >A (IVS8+2T>A)/BRCA2 c.2830A > T (p.Lys944Ter) and BRCA1 c.3752_3755GTCT (p.Ser1253fs)/BRCA2 c.425+2T $>$ C (IVS4+2T $>$ C) have not been described together so far. The DM in BRCA2, c.631G>A (p.Val211Ile) and c.7008-2A>T (IVS13-2A>T), found in three unrelated probands, was previously reported in further unrelated patients. Due to its peculiarity, it is likely that both pathogenic variants descend from a common ancestor and, therefore, are founder mutations. Interestingly, analyzing the tumor types occurring in DH and DM families, we observed ovarian cancer only in $\mathrm{DH}$ families, probably due to the presence in $\mathrm{DH}$ patients of $B R C A 1$ pathogenic variants, which predispose one more to ovarian cancer onset. Furthermore, male breast cancer and pancreatic cancer ensued in families with DM but not with DH. These data confirm that BRCA2 pathogenic variants have greater penetrance to develop breast cancer in men and are associated with an increased risk of pancreatic cancer.
\end{abstract}

Keywords: double heterozygosity (DH); double mutations (DM); BRCA1; BRCA2; hereditary breast and ovarian cancer

\section{Introduction}

The presence of genetic factors plays a large role in breast cancer (BC) and ovarian cancer (OC) onset $[1,2]$. About $5-10 \%$ of breast tumors and 10-15\% of ovarian tumors are hereditary, and approximately $30 \%$ of cases are attributed to pathogenic variants in BRCA1/2 genes [3]. Many nongenetic factors, such as the degree of economic development, social status, and lifestyle factors (such as obesity) affect the probability of developing BC or OC [4], and the risks associated with BRCA1 and BRCA2 pathogenic variants differ in various geographical areas, highlighting the importance of evaluating the risk for each patient regarding their own genetic and environmental context [5]. 
The characterization of germline pathogenic variants in the BRCA1 and BRCA2 genes are relevant for prevention setting and for the clinical management of hereditary breast and ovarian cancer (HBOC) [6].

The mutation frequency of these genes occurs within the population in a variable way as to $1 / 400$ up to 1/800 individuals, and the prevalence of founder mutations in some ethnic groups is much higher, as in Ashkenazi Jewish, where it is 1/40 [7]. Double heterozygosity (DH) of BRCA1 and BRCA2 is extremely a rare event in general population [7]. It is estimated at $1.8 \%$ in Ashkenazi Jewish, due to founder mutations, whereas in non-Ashkenazi Jewish it is in the range of $0.22-0.83 \%$ [8]. Indeed, few DH cases have been reported worldwide [9-31] as well as in the Italian population [7,32-36]. Additionally, the DM in the same gene, BRCA1 or BRCA2, is rare and reported in few cases [23,24,36-40].

Here, we describe two cases of DH in BRCA1/BRCA2 genes and three cases of DM in the BRCA2 gene in five probands with breast and ovarian cancer and in their families.

\section{Materials and Methods}

\subsection{Patients}

This study was carried out in accordance with the World Medical Association Helsinki Declaration, adopted in 1964 and amended in 1975, 1983, 1989, 1996, and 2000. Informed consent was obtained from all subjects, and the study was approved and conducted according to the ethical guidelines of the University of Campania "Luigi Vanvitelli" (n.469-23 July 2019).

The five DH cases described were ascertained among 645 patients tested for BRCA1 and BRCA2 pathogenic variants at our center, Unity of Clinical and Molecular Pathology, University of Campania "Luigi Vanvitelli" of Naples. All the selected patients received genetic counselling. The case history was collected and the pedigree was generated with (i) the personal history of cancers (ii) the family history of breast/ovarian and other cancers.

Out of 5 proband, all women, three were affected with BC, one bilateral breast cancer (bBC) and one ovarian cancer (OC). All came from the same region, Campania, a region of Southern Italy with Caucasian ethnicity. Mutational analysis was extended to family members of mutated probands, and at least one family member was available for genetic testing.

\subsection{Mutation Analysis}

Peripheral blood samples were collected from patients. The extraction of genomic DNA from peripheral blood lymphocytes was performed using the Wizard Genomic DNA purification kit (Promega Corporation, Madison, WI, USA). A mutational analysis of exons and adjacent intronic regions of $B R C A 1 / B R C A 2$ genes was performed with next-generation sequencing (NGS), as previously described [41]. The presence of the pathogenic variant was confirmed on a second blood sample by Sanger sequencing, as previously described [42].

\section{Results}

We observed two cases of $\mathrm{DH}(0.3 \%)$ in BRCA1/2 genes in a cohort of 645 probands affected with breast or ovarian cancer. Particularly, we found one patient with $\mathrm{DH}$ in a cohort of $533(0.2 \%) \mathrm{BC}$ patients and one patient with $\mathrm{DH}$ in a cohort of $59(1.7 \%)$ OC patients. In addition, we found three cases of DM $(0.5 \%)$ in the BRCA2 gene.

The clinical characteristics of the probands and the corresponding pathogenic variants are listed in Tables 1 and 2.

All the pathogenic variants had been previously described as "Pathogenic" in the public variant databases ClinVar (https://www.ncbi.nlm.nih.gov/clinvar/variation/) [43], except the BRCA2 c.425+2T >A (IVS4+2T>C), classified as "Likely Pathogenic". 
Table 1. Probands with double heterozygosity (DH) in the BRCA1/2 genes.

\begin{tabular}{cclcc}
\hline Proband Number & Gene & \multicolumn{1}{c}{ Pathogenic Variant } & Molecular Consequence & dbSNP ID \\
\hline \multirow{2}{*}{1} & BRCA1 & c.547+2T $>$ A (IVS8+2T $>$ A) & Splice & rs80358047 \\
& $B R C A 2$ & c.2830A $>$ T (p.Lys944Ter) & Nonsense & rs80358533 \\
\hline \multirow{2}{*}{2} & $B R C A 1$ & c.3752_3755GTCT (p.Ser1253fs) & Frameshift & rs80357868 \\
& $B R C A 2$ & c.425+2T $>$ C (IVS4+2T $>$ C) & Splice & rs876661045 \\
\hline
\end{tabular}

Table 2. Probands with double mutation (DM) in the BRCA2 genes.

\begin{tabular}{|c|c|c|c|c|}
\hline Proband Number & Gene & Pathogenic Variant & Molecular Consequence & $d b S N P I D$ \\
\hline \multirow[b]{2}{*}{3} & $B R C A 2$ & c.631G >A (p.Val211Ile) & Splice & rs80358871 \\
\hline & $B R C A 2$ & c.7008-2A > T (IVS13-2A $>$ T) & Splice & rs 81002823 \\
\hline \multirow{2}{*}{4} & $B R C A 2$ & c.631G >A (p.Val211Ile) & Splice & rs80358871 \\
\hline & $B R C A 2$ & c.7008-2A>T (IVS13-2A > T) & Splice & rs81002823 \\
\hline \multirow{2}{*}{5} & $B R C A 2$ & c.631G >A (p.Val211Ile) & Splice & rs80358871 \\
\hline & $B R C A 2$ & c. $7008-2 \mathrm{~A}>\mathrm{T}(\mathrm{IVS} 13-2 \mathrm{~A}>\mathrm{T})$ & Splice & rs81002823 \\
\hline
\end{tabular}

\subsection{Family 1}

The patient with pathogenic variants c.547+2T $>$ A (IVS8+2T $>$ A) in BRCA1 and c.2830A $>$ T (p.Lys944Ter) in BRCA2 has already been described [35]. After 2013, the mutation analysis was extended to other family members. The proband was a 49-year-old woman affected with bilateral BC. The patient referred other cases of tumors in her family (Figure 1).

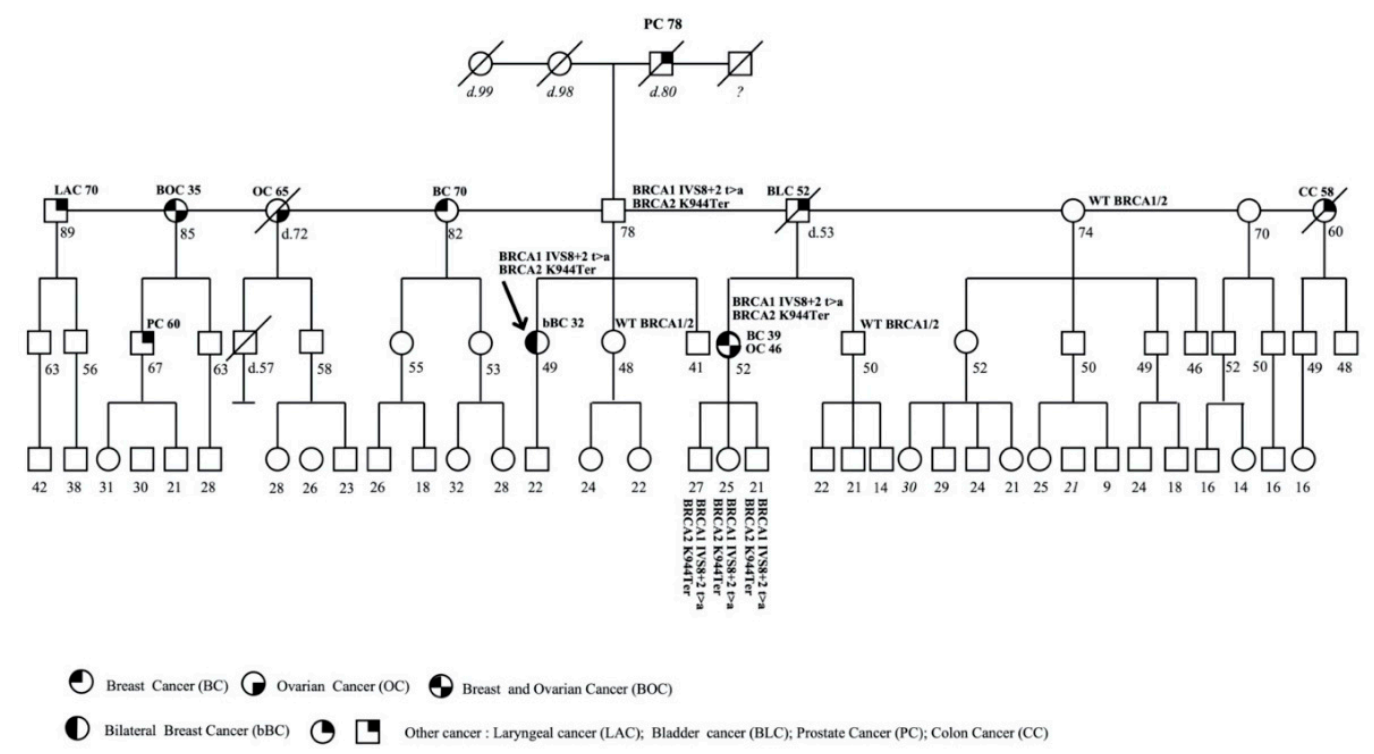

Figure 1. Pedigree of family 1 carrying the double heterozygosity $(\mathrm{DH})$ in $B R C A 1 \mathrm{c} .547+2 \mathrm{~T}>\mathrm{A}$ $(\mathrm{IVS} 8+2 \mathrm{~T}>\mathrm{A})$ and BRCA2 c.2830A $>$ T (p.Lys944Ter). The ages at diagnosis are indicated in brackets.

The mother's family is not displayed in the pedigree because no cancer types were reported from the maternal side. It is noteworthy that mutational analysis showed that the proband's mother did not carry either of the pathogenic variants, while the unaffected father carried both the BRCA1 and BRCA2 pathogenic variants. The analysis was performed in the unaffected sister of 48 years, one healthy paternal aunt of 74 years, and one paternal cousin affected with BC and OC, diagnosed at 39 and 46 years, respectively. DH was carried by her cousin, affected with BC and OC, while the paternal aunt and the sister of proband reported a normal profiling of both BRCA1 and BRCA2. 
Subsequently, molecular analysis was extended to three sons of the cousin with $\mathrm{DH}$, two men of 27 and 21 years, respectively, and one 25-year-old woman, and to the brother of 50 years; all individuals were healthy. DH was carried by all sons, while the brother carried a wild-type profiling of both genes.

\subsection{Family 2}

The proband was a 36-year-old woman affected with OC. Mutational analysis revealed the BRCA1 and BRCA2 pathogenic variants, c.3752_3755GTCT (p.Ser1253fs) and c.425+2T>C (IVS4+2T $>$ C), respectively.

The proband reported other cases of cancer in family on the maternal side (Figure 2). The mother's brother, who died at 30 years, was affected with leukemia and diagnosed at 28 years, while the cousin of 40 years was affected with colon cancer (CC), diagnosed at 37 years. The analysis was performed in the unaffected mother, who was 70 years old, and in the cousin affected with CC; both subjects showed DH. The proband's son was not tested because he was 6 years old. To date, no other family member has consented to the testing.

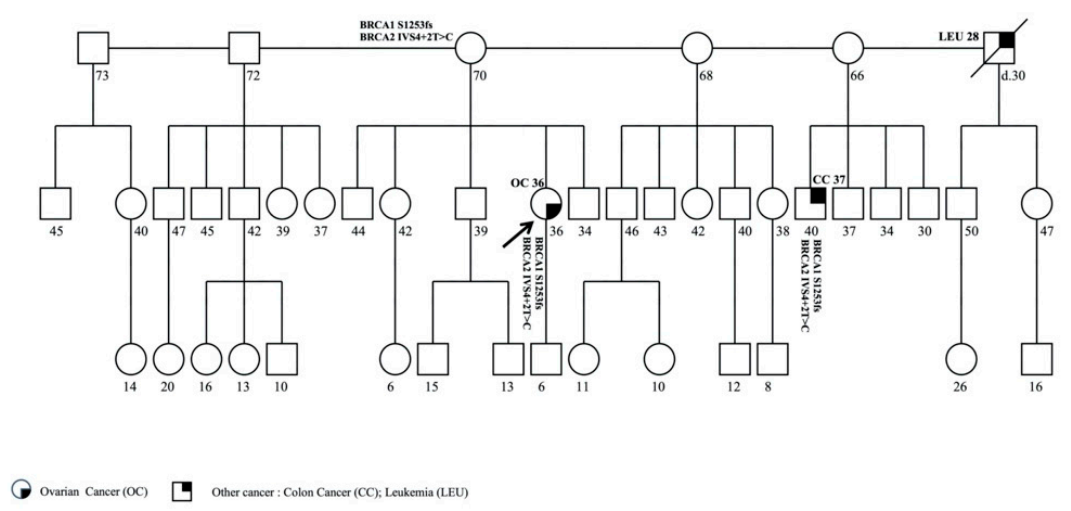

Figure 2. Pedigree of family 2 carrying the DH in BRCA1 c.3752_3755GTCT (p.Ser1253fs) and BRCA2 c. $425+2 \mathrm{~T}>\mathrm{C}(\mathrm{IVS} 4+2 \mathrm{~T}>\mathrm{C})$. The ages at diagnosis are indicated in brackets.

\subsection{Family 3}

The proband was a 46-year-old woman affected with BC, diagnosed at 45 years. Molecular analysis showed two pathogenic variants in BRCA2 gene, c.631G $>$ A (p.Val211Ile) and c.7008-2A $>$ T (IVS13-2A $>$ T).

The patient reported other cases of $\mathrm{BC}$ in her family on the maternal side (Figure 3). The mother was affected with BC, diagnosed at 69 years; the mother's brother, affected with male BC, died at 73 years a few months after diagnosis. The latter's daughter, who was 45 years old, was affected with $\mathrm{BC}$ and diagnosed at 43 years. Molecular analysis, performed in the mother and in the proband's cousin of 45 years, revealed DM in both family members. To date, no other family member has received genetic testing.

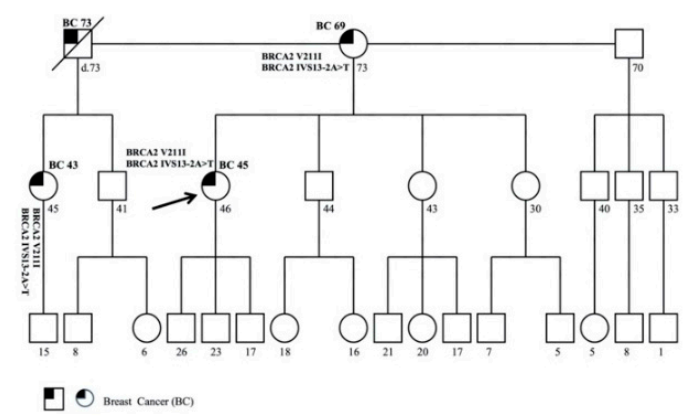

Figure 3. Pedigree of family 3 carrying the DM in BRCA2 c.631G $>A$ (p.Val211Ile) and c.7008-2A $>$ T (IVS13-2A $>$ T). The ages at diagnosis are indicated in brackets. 


\subsection{Family 4}

The proband was a 77-year-old woman affected with BC who was diagnosed at 65 years. She reported two pathogenic variants in the BRCA2 gene, c.631G $>$ A (p.Val211Ile) and c.7008-2A $>$ T (IVS13-2A>T).

She showed a further seven BC cases in the family and one case of CC (Figure 4). Molecular analysis was performed in the unaffected children of 52 and 54 years old, with the son of 54 years reporting a normal BRCA2 profile and the daughter of 52 years displaying DM. The analysis was also extended to the latter's sons, of 27 and 18 years, and this revealed the presence of DM only in the son of 18 years.

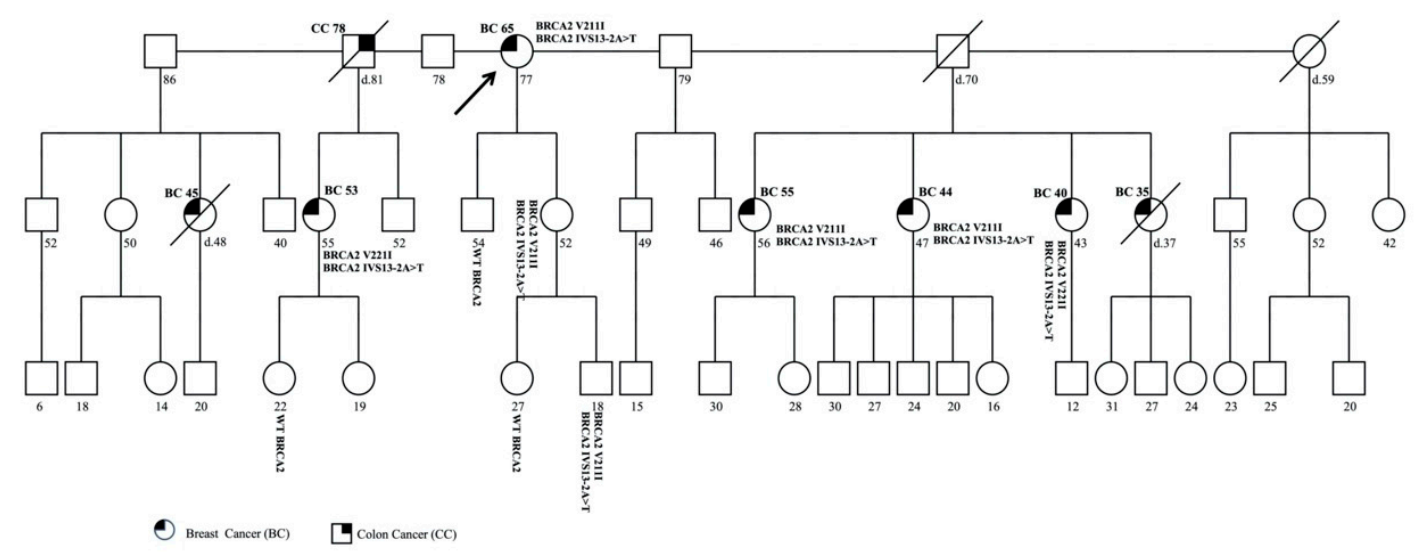

Figure 4. Pedigree of family 4 carrying the DM in BRCA2 c.631G $>$ A (p.Val211Ile) and c.7008-2A $>$ T (IVS13-2A $>$ T). The ages at diagnosis are indicated in brackets.

In an analysis performed in the proband's nieces, four women of 55, 56, 47, and 43 years, all affected with BC, showed DM in all of them.

Subsequently, one of the daughters of the 55-year-old niece with BC and DM was tested, with a negative result. To date, the other family members have decided not to undergo genetic testing.

\subsection{Family 5}

The proband was a 62-year-old woman affected with BC who was diagnosed at 60 years. Molecular analysis showed two pathogenic variants in BRCA2 gene, c.631G>A (p.Val211Ile) and c.7008-2A > T (IVS13-2A > T).

The patient reported other cancer cases of in her family (Figure 5); a sister was affected with bBC and was diagnosed at 43 years, and the brother, who was 65 years old, received a diagnosis of leukemia at 36 years. A 70-year-old paternal cousin was affected with BC and diagnosed at 60 years. Moreover, the proband's father, who was affected with pancreatic cancer, died at 65 years, and three paternal cousins with BC died at 67,60 , and 64 years.

The analysis was performed in the unaffected daughters of 35 and 41 years. DM was identified only in the daughter of 35 years. Moreover, the mutational analysis was executed in the sister of 56 years with $\mathrm{bBC}$, who showed DM in the BRCA2 gene. Subsequently, the analysis was extended to the unaffected daughters of the latter, of 35 and 30 years, who had negative results, and the daughter with BC, diagnosed at 32 years, who showed the DM and died at the same age, a few months after testing. In addition, the analysis was extended to the proband unaffected brother of 59 years old and reported a wild-type profiling, and to the proband's cousin of 70 years who was affected with BC, reporting DM. The presence of DM in the paternal cousin indicates that the BRCA2 double mutation was very likely inherited from the paternal side. 


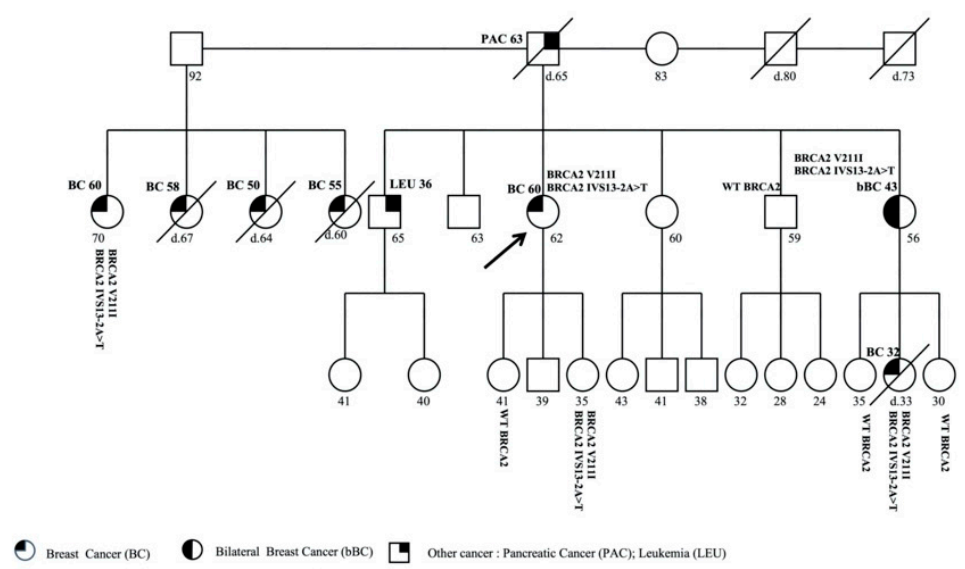

Figure 5. Pedigree of family 5 carrying the DM in BRCA2 c.631G >A (p.Val211Ile) and c.7008-2A >T (IVS13-2A $>$ T). The ages at diagnosis are indicated in brackets.

Table 3 summarizes the results of the genetic tests carried out on probands with DH and family members of the probands undergoing the test. No family member has inherited a single pathogenic variant. All the family members tested, affected with cancer, showed DH. Out of nine subjects with $\mathrm{DH}$, four were affected with cancer (2 probands +2 family members) and $1 / 4(25 \%)$ was affected with bilateral breast cancer (bBC), $1 / 4(25 \%)$ with OC, $1 / 4$ (25\%) with BC and OC, and 1/4 (25\%) with CC, while five were healthy. The phenotypic expression in $\mathrm{DH}$ subjects varied from $\mathrm{bBC}$ at the age of 32 to healthy at the age of 78 .

Table 3. Families tested for DH in BRCA1/2.

\begin{tabular}{|c|c|c|c|c|c|}
\hline Family Number & Family Members & Years & Diagnosis & Age at Onset & Genetic Test Result \\
\hline \multirow{10}{*}{1} & proband & 49 & $\mathrm{bBC}$ & \multirow{2}{*}{32} & $\mathrm{DH}$ \\
\hline & father & 78 & healthy & & $\mathrm{DH}$ \\
\hline & mother & 68 & healthy & & NEG \\
\hline & paternal aunt & 74 & healthy & & NEG \\
\hline & sister & 48 & healthy & & NEG \\
\hline & cousin female & 52 & BC-OC & $39-46$ & $\mathrm{DH}$ \\
\hline & cousin male & 50 & healthy & & NEG \\
\hline & nephew & 27 & healthy & & $\mathrm{DH}$ \\
\hline & nephew & 21 & healthy & & $\mathrm{DH}$ \\
\hline & niece & 25 & healthy & & $\mathrm{DH}$ \\
\hline \multirow{3}{*}{2} & proband & 36 & OC & \multirow{2}{*}{36} & $\mathrm{DH}$ \\
\hline & mother & 70 & healthy & & $\mathrm{DH}$ \\
\hline & cousin male & 40 & $\mathrm{CC}$ & 37 & $\mathrm{DH}$ \\
\hline
\end{tabular}

$\mathrm{bBC}=$ bilateral breast cancer; $\mathrm{OC}=$ ovarian cancer; $\mathrm{BC}=$ breast cancer; $\mathrm{CC}$ : colon cancer.

Table 4 summarizes the results of the genetic tests carried out on probands with DM and family members of the probands undergoing the test. No family member has inherited a single pathogenic variant. All the family members tested who were affected with cancer showed DM. Out of 15 subjects with DM, 12 were affected with cancer (3 probands +9 family members), 11/12 (92\%) were affected with $\mathrm{BC}$ and $1 / 12(8 \%)$ with $\mathrm{bBC}$, while three were healthy. The phenotypic expression in DM subjects varied from $B C$ at the age of 32 to healthy at the age of 52 .

Figure 6 reports the number and percentages of various types of tumors occurring in families with DH in BRCA1/2 and DM in BRCA2. 
Table 4. Families tested for DM in BRCA2.

\begin{tabular}{cccccc}
\hline Family Number & Family Members & Years & Diagnosis & Age at Onset & Genetic Test Result \\
\hline \multirow{3}{*}{3} & proband & 46 & BC & 45 & DM \\
& mother & 73 & BC & 69 & DM \\
& cousin female & 45 & BC & 43 & DM \\
\hline proband & 77 & BC & 65 & DM \\
daughter & 52 & healthy & & DM \\
& son & 54 & healthy & & NEG \\
& grandchildren & 27 & healthy & & DM \\
grandchildren & 18 & healthy & \multirow{2}{*}{ DM } & DM \\
niece & 55 & BC & 53 & DM \\
& niece & 43 & BC & 40 & DM \\
niece & 56 & BC & 55 & NEG \\
niece & 47 & BC & 44 & DM \\
& grand-niece & 22 & healthy & & NEG \\
& proband & 62 & BC & \multirow{2}{*}{60} & DM \\
brother & 59 & healthy & & DM \\
sister & 56 & bBC & 43 & NEG \\
daughter & 35 & healthy & & NEG \\
daughter & 41 & healthy & & NEG \\
niece & 35 & healthy & & DM \\
& niece & 30 & healthy & & DM \\
\hline
\end{tabular}

$\mathrm{bBC}=$ bilateral breast cancer; $\mathrm{BC}=$ breast cancer; + : dead.

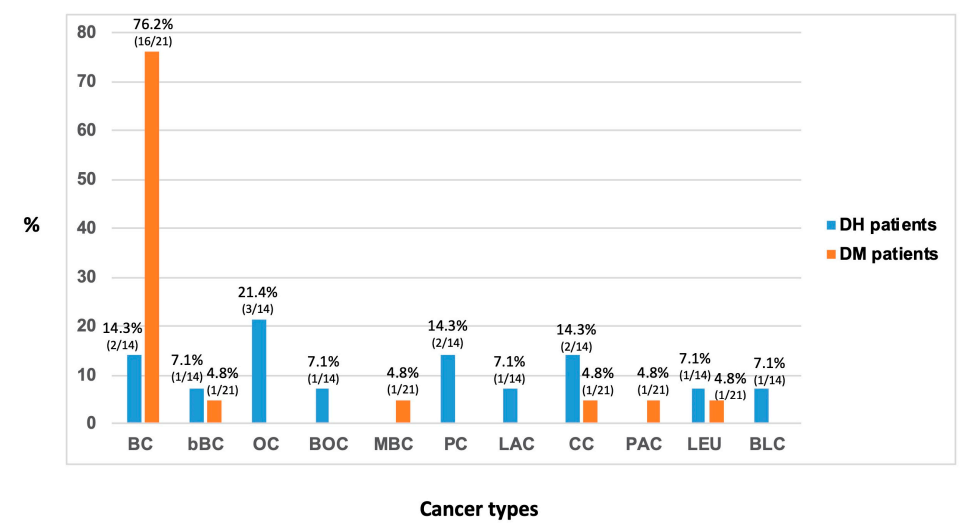

Figure 6. Cancer types occurring in families with DH and DM. BC: breast cancer; bBC: bilateral breast cancer; OC: ovarian cancer; BOC: breast ovarian cancer; $\mathrm{MBC}$ : male breast cancer; PC: prostate cancer; LAC: laryngeal cancer; CC: colon cancer; PAC: pancreatic cancer; LEU: leukemia; BLC: bladder cancer.

The average age of onset of various cancer types occurring in families with $\mathrm{DH}$ in $B R C A 1 / 2$ and DM in BRCA2 is reported in Table 5.

Table 5. Number and onset age of various type of cancers that occur in families with DH and DM.

\begin{tabular}{cccccccccccc}
\hline & BC & bBC & OC & BOC & MBC & PC & LAC & CC & PAC & LEU & BLC \\
\hline $\mathrm{DH}$ & $2(54.5)$ & $1(32)$ & $3(49)$ & $1(35)$ & - & $2(69)$ & $1(70)$ & $2(47.5)$ & - & $1(28)$ & $1(52)$ \\
\hline $\mathrm{DM}$ & $16(50.6)$ & $1(43)$ & - & - & $1(73)$ & - & - & $1(78)$ & $1(63)$ & $1(36)$ & - \\
\hline
\end{tabular}

BC: breast cancer; bBC: bilateral breast cancer; OC: ovarian cancer; BOC: breast ovarian cancer; MBC: male breast cancer; PC: prostate cancer; LAC: laryngeal cancer; CC: colon cancer; PAC: pancreatic cancer; LEU: leukemia; BLC: bladder cancer. 
Additionally, we completed a review of the worldwide literature using the PubMed database (https://www.ncbi.nlm.nih.gov/pubmed). From 1997 to 2019, 31 articles described a DH in BRCA1/2 and 7 articles described a DM in BRCA2. The results are summarized in Tables 6 and 7, respectively.

Table 6. BRCA1 and BRCA2 DH reported worldwide (ClinVar nomenclature).

\begin{tabular}{|c|c|c|c|c|c|}
\hline BRCA1 & $B R C A 2$ & Cancer & $\begin{array}{c}\text { Age at } \\
\text { Diagnosis }\end{array}$ & $\begin{array}{l}\text { Geographic } \\
\text { Area }\end{array}$ & References \\
\hline $\begin{array}{c}\text { c.68_69delAG } \\
\text { (185delAG) (p.Glu23fs) }\end{array}$ & $\begin{array}{l}\text { c.5946delT (6174delT) } \\
\text { (p.Ser1982Argfs*22) }\end{array}$ & $\begin{array}{c}\text { BC } \\
\text { OC } \\
\text { BOC } \\
\text { Healthy }\end{array}$ & 35 at 57 & $\begin{array}{c}\text { Hungarian, } \\
\text { Jewish, } \\
\text { Ashkenazi J, } \\
\text { Dutch, } \\
\text { Israel }\end{array}$ & [9-14] \\
\hline $\begin{array}{l}\text { c.5266dupC (5382insC) } \\
\text { (p.Gln1756Profs) }\end{array}$ & $\begin{array}{l}\text { c.5946delT (6174delT) } \\
\text { (p.Ser1982Argfs*22) }\end{array}$ & $\begin{array}{c}\mathrm{BC} \\
\mathrm{BOC}\end{array}$ & 33 at 47 & $\begin{array}{l}\text { Ashkenazi J, } \\
\text { Dutch }\end{array}$ & {$[11,13,15,16]$} \\
\hline c.3768_3769AG (p.Glu1257fs) & $\begin{array}{l}\text { c.5946delT (6174delT) } \\
\text { (p.Ser1982Argfs*22) }\end{array}$ & $\begin{array}{c}\mathrm{BC} \\
\mathrm{BOC}\end{array}$ & 30 at 41 & $\begin{array}{l}\text { Ashkenazi J, } \\
\text { Australian }\end{array}$ & {$[17,18]$} \\
\hline $\begin{array}{l}\text { c.3695_3699GTAAA } \\
\text { (p.Val1234fs) }\end{array}$ & c.1813dupA (p.Ile605Asnfs) & $\begin{array}{c}\mathrm{BC} \\
\mathrm{OC} / \mathrm{CC}\end{array}$ & 40,61 & Germany & [19] \\
\hline $\begin{array}{c}\text { c.2389G }>\text { T } \\
\text { (p.Glu797Ter) }\end{array}$ & c.3068dupA (p.Asn1023Lysfs) & $\mathrm{BC}$ & 35 & Scottish & [20] \\
\hline $\begin{array}{c}\text { c.5080G }>\text { T } \\
\text { (p.Glu1694Ter) }\end{array}$ & c.6405_6409del (p.Asn2135fs) & OC & 49 & German & [21] \\
\hline c.5123C>A (p.Ala1708Glu) & c.6275_6276del (p.Leu2092fs) & $\mathrm{BC}$ & 28 & Spanish & [22] \\
\hline c.1504_1508del (p.Leu502fs) & c.2796_2797CA (p.Thr933fs) & $\mathrm{BC}$ & 26 & Korea & [23] \\
\hline c.4981G>T (p.Glu1661Ter) & c.5946_5949del (p.Ser1982fs) & $\mathrm{BC}$ & 33 & Korea & [23] \\
\hline c.2685_2686del (p.Pro897fs) & $\begin{array}{c}\text { c.3487del } \\
\text { (p.Asp1163fs) }\end{array}$ & $\mathrm{BOC}$ & 40,45 & Dutch & [13] \\
\hline c.2685_2686del (p.Pro897fs) & c.4449del (p.Asp1484fs) & $\mathrm{BC}$ & 50 & Dutch & [13] \\
\hline c.962G >A (p.Trp321Ter) & c.3170_3174del (p.Lys1057fs) & $\mathrm{BC}$ & 37 & $\begin{array}{c}\text { Mixed } \\
\text { European }\end{array}$ & [24] \\
\hline c.4287C >A (p.Tyr1429Ter) & c.7738C > T (p.Gln2580Ter) & $\mathrm{BC}$ & 37 & Italy & [32] \\
\hline c.3331_3334del (p.Gln1111fs) & c. $631+2 \mathrm{~T}>\mathrm{G}(\mathrm{IVS7}+2 \mathrm{~T}>\mathrm{G})$ & $\begin{array}{l}\mathrm{BC} \\
\mathrm{CC}\end{array}$ & 34,35 & Australian & [25] \\
\hline $\begin{array}{l}\text { c.5266dupC (5382insC) } \\
\text { (p.Gln1756Profs) }\end{array}$ & c.5796_5797del (p.His1932fs) & $\mathrm{BC} / \mathrm{OC}$ & 44 & Italy & [33] \\
\hline c.5096G>A (p.Arg1699Gln) & c. $631+4 \mathrm{~A}>\mathrm{G}(\mathrm{IVS7}+4 \mathrm{~A}>\mathrm{G})$ & $\mathrm{BOC}$ & 53,59 & Danish & [26] \\
\hline c.835_835delC (p.His279Metfs) & c.8195T>G (p.Leu2732Ter) & $\mathrm{BC}$ & 43 & $\begin{array}{l}\text { Northern } \\
\text { Italy }\end{array}$ & [34] \\
\hline c. $1687 \mathrm{C}>\mathrm{T}$ (p.Gln563Ter)) & c.6697C > T (p.Gln2157Ter) & $\mathrm{BC}$ & 30 & $\begin{array}{l}\text { Northern } \\
\text { Italy }\end{array}$ & [34] \\
\hline c.2401_2402TG (p.Val802fs) & c.4284dup (p.Gln1429fs) & $\mathrm{BC}$ & 46 & $\begin{array}{l}\text { Northern } \\
\text { Italy }\end{array}$ & [34] \\
\hline c.3916_3917del (p.Leu1306fs) & 5608delG (p.Val1794Ter) & $\mathrm{BC}$ & 52 & $\begin{array}{l}\text { Northern } \\
\text { Italy }\end{array}$ & [34] \\
\hline c.1961del (p.Lys654fs) & $\begin{array}{l}\text { c.1672del } \\
\text { (p.Ile558fs) }\end{array}$ & OC & 50 & Non-Ashkenazi & [27] \\
\hline $\begin{array}{l}\text { c.5266dupC (5382insC) } \\
\text { (p.Gln1756Profs) }\end{array}$ & c.4827_4828TG (p.Val1610fs) & $\mathrm{BC}$ & 40 & Ashkenazi & [27] \\
\hline $\begin{array}{l}\text { c.5266dupC (5382insC) } \\
\text { (p.Gln1756Profs) }\end{array}$ & c.5645C>A (p.Ser1882Ter) & $\mathrm{BC}$ & 37 & Germany & [19] \\
\hline $\begin{array}{l}\text { c.68_69delAG (185delAG) } \\
\text { (p.Glu23fs) }\end{array}$ & $\begin{array}{l}\text { c.5718_5719delCT } \\
\text { (p.Leu1908Argfs) }\end{array}$ & $\mathrm{BC}$ & 32 & Germany & [19] \\
\hline c.962G>A (p.Trp321Ter) & c.2231C>G (p.Ser744Ter) & $\mathrm{BC}$ & 31 & Germany & [19] \\
\hline
\end{tabular}


Table 6. Cont

\begin{tabular}{|c|c|c|c|c|c|}
\hline BRCA1 & $B R C A 2$ & Cancer & $\begin{array}{c}\text { Age at } \\
\text { Diagnosis }\end{array}$ & $\begin{array}{l}\text { Geographic } \\
\text { Area }\end{array}$ & References \\
\hline c.3910delG (p.Glu1304Lysfs) & c.2830A > T (p.Lys944Ter) & BC & 40 & Germany & [19] \\
\hline $\begin{array}{c}\text { c.5277+1de } \\
\text { (IVS20+1delG) }\end{array}$ & c.658_659del (p.Val220fs) & BC & 39 & Germany & [19] \\
\hline c.390C >A (p.Tyr130Ter) & $\begin{array}{c}\text { c.3018del } \\
\text { (p.Gly1007fs) }\end{array}$ & BC & 26,45 & Germany & [28] \\
\hline c.4981G>T (p.Glu1661Ter) & c.5946_5949del (p.Ser1982fs) & BC & 33 & Germany & [28] \\
\hline c.3627dupA (p.Glu1210Argfs) & $\begin{array}{l}\text { c.6724_6725delGA } \\
\text { (p.Asp2242Phefs) }\end{array}$ & BC & 26 & Germany & [28] \\
\hline c.5030_5033del (p.Thr1677fs) & c.1399A > T (p.Lys467Ter) & $\mathrm{BC}$ & 35 & Germany & [28] \\
\hline c.2641G > T (p.Glu881Ter) & c.8162T>A (p.Leu2721His) & $\mathrm{BC}$ & 42 & $\begin{array}{l}\text { South } \\
\text { African }\end{array}$ & [29] \\
\hline c. $547+2 \mathrm{~T}>\mathrm{A}(\mathrm{IVS} 8+2 \mathrm{~T}>\mathrm{A})$ & c.2830A > T (p.Lys944Ter) & $\mathrm{bBC}$ & 32 & $\begin{array}{l}\text { Southern } \\
\text { Italy }\end{array}$ & [35] \\
\hline c.188T>A (p.Leu63Ter) & $\begin{array}{l}\text { c.5576_5579del } \\
\text { (p.Ile1859fs) }\end{array}$ & BC & 59 & Japan & [30] \\
\hline c.1687C>T (p.Gln563Ter) & c.9976A>T (p.Lys3326Ter) & $\mathrm{BC}$ & 40 & $\begin{array}{l}\text { Southern } \\
\text { Italy }\end{array}$ & [7] \\
\hline $\begin{array}{c}\text { c.5095C>T } \\
\text { (p.Arg1699Trp) }\end{array}$ & $\begin{array}{c}c .1238 d e l T \\
\text { (p.Leu413HisfsTer17) }\end{array}$ & $\mathrm{bBC}$ & 41,54 & Italy & [36] \\
\hline $\begin{array}{c}\text { c. } 547+2 \mathrm{~T}>\mathrm{A} \\
(\mathrm{IVS} 8+2 \mathrm{~T}>\mathrm{A})\end{array}$ & c.2830A > T (p.Lys944Ter) & BC & 32 & $\begin{array}{l}\text { Southern } \\
\text { Italy }\end{array}$ & This paper \\
\hline $\begin{array}{l}\text { c.3752_3755delGTCT } \\
\text { (p.Ser1253fs) }\end{array}$ & c. $425+2 \mathrm{~T}>\mathrm{C}(\mathrm{IVS} 4+2 \mathrm{~T}>\mathrm{C})$ & OC & 36 & $\begin{array}{l}\text { Southern } \\
\text { Italy }\end{array}$ & This paper \\
\hline
\end{tabular}

Table 7. BRCA2 DM reported worldwide (ClinVar nomenclature).

\begin{tabular}{|c|c|c|c|c|}
\hline$B R C A 2$ & Cancer & Age at Diagnosis & Geographic Area & Reference \\
\hline $\begin{array}{l}\text { c.1547del (p.Phe516fs) and } \\
\text { c.4599A >C (p.Lys1533Asn) }\end{array}$ & LEU & 37 & Korea & [23] \\
\hline $\begin{array}{c}\text { c.2905C }>\text { T (p.Gln969Ter) and } \\
\text { c.6447_6448dupTA } \\
\text { (p.Lys2150IlefsTer19) }\end{array}$ & $\mathrm{BC}$ & 49 & Italy & [36] \\
\hline $\begin{array}{l}\text { c.631G }>\text { A (p.Val211Ile) and } \\
\text { c.7008-2A }>\text { T (IVS13-2A }>\text { T) }\end{array}$ & BOC & 45 at 65 & $\begin{array}{l}\text { Italy } \\
\text { USA }\end{array}$ & $\begin{array}{c}\text { [36-39] This paper } \\
\text { [40] }\end{array}$ \\
\hline $\begin{array}{c}\text { c. } 4889 \mathrm{C}>\mathrm{G} \text { (p.Ser1630Ter) and } \\
\text { c.5344C }>\text { A (p.Gln1782Lys) }\end{array}$ & $\mathrm{BC}$ & 46 & White & [24] \\
\hline
\end{tabular}

\section{Discussion}

In the last few years, the development of next-generation sequencing (NGS) has enhanced the ability to test for many genes simultaneously, has allowed progress in the field of cancer genetics and lowered the cost of genetic testing. This advance has led to greater insights into hereditary cancer and consequently to confer significant risk for either breast or ovarian cancer [3].

To date, the co-existence in an individual of $\mathrm{DH}$ in $B R C A 1$ and $B R C A 2$ genes is a very rare condition in most populations and, therefore, little is known about the pathological characteristics of tumors in patients with $\mathrm{DH}$ and their family history. Indeed, only 31 studies worldwide have reported patients with $\mathrm{DH}$ in the BRCA1/2 genes. Table 6 is a list of DH cases identified in Ashkenazi Jewish population and non-Ashkenazi [7,9-36].

In this study we have identified two cases with $\mathrm{DH}$ for pathogenic variants in $B R C A 1 / 2$ genes with a frequency of $0.3 \%$, which falls within the range previously reported $(0.3-1.8 \%)[44,45]$. Indeed, in different ethnic groups with BC and/or OC, a value of $0.3 \% \mathrm{DH}$ was reported [44], while in the Ashkenazi population a percentage of $1.8 \%$ was found [8]. 
To our knowledge, the DH found in family 1 BRCA1 c.547+2T >A (IVS8+2T >A)/BRCA2 c.2830A $>$ T (Lys944Ter) and DH found in family 2, BRCA1 c.3752_3755GTCT (p.Ser1253fs)/BRCA2 c.425+2T >C (IVS4+2T >C) (see Table 1), have not been described together so far. The data obtained from the analysis on families show that these pathogenic variants co-segregate. The BRCA1 c.3752_3755GTCT (p.Ser1253fs) was previously observed in women of Italian origin with OC [46]. Moreover, the $B R C A 2$ c.425+2T $>C$ (IVS4+2T>C), occurring in family 2 , has not been reported in individuals with $B R C A 2-$ related disease and in association with other BRCA mutations. This variant may disrupt the consensus splice site and lead to a loss of protein function. The currently available evidence indicates that additional data are needed to prove that this variant is pathogenic [47]. Additionally, it could represent the first case in which this variant is found in a patient with OC and associated with another $B R C A$ pathogenic variant.

Moreover, we have identified three unrelated cases with the same DM in BRCA2 gene with a frequency of $0.5 \%$. To our knowledge, very few studies worldwide have reported patients with DM in BRCA2 gene (Table 7).

The DM in BRCA2, c.631G >A (p.Val211Ile)/c.7008-2A > T (IVS13-2A >T), as shown in Table 7, was previously reported in Italian unrelated patients [36-39]. Moreover, c.631G>A (p.Val211Ile) was firstly reported as a single mutation in an Italian breast and ovarian cancer patient [48].

Both mutations alter normal mRNA splicing, leading to the expression of a truncated protein [37,39]. Since germinal mutations affecting a single allele in BRCA2 increase susceptibility to BC and OC, while certain bi-allelic mutations cause Fanconi anemia (FA) [49], in similar cases, it is crucial to establish whether the two mutations are in cis or in trans and, therefore, whether are on a same allele or on different alleles. To date, these two variants have never been reported in trans in literature. Furthermore, the BRCA2 c.7008_2A > T (IVS13-2A>T) mutation, is unlikely to contribute to cancer risk in the context of the allele described here, since it lies downstream of another mutation that completely abolishes the synthesis of a functional gene product. These variants were confirmed to occur on the same chromosome (in cis phase) by retro-transcription RT-PCR analysis or segregation analysis in family studies $[37,39,50]$.

We assume that these pathogenic variants are in cis because all tested family members show DM, none has inherited a single variant. This finding indicates that these pathogenic variants co-segregate thus establishing that they affect the same allele. Moreover, in carriers of these pathogenic variants, no traces of FA-associated tumors are present.

The BRCA2 DM c.631G>A (p.Val211Ile)/c.7008-2A>T (IVS13-2AT) occur more frequently in Italian regions [36-39]. This allelic frequency in Italian regions supports the assumption that such pathogenic variants might be evident in geographically restricted areas and descend from a common ancestor, as suggested by the presence of a unique BRCA2 allele in Italy.

The increased risk of cancer in DH carriers, as in patients with a single mutation in $B R C A$ genes, is not limited to breast and ovarian cancer but also involves other cancers [34]. In line with this evidence, among the tumors reported in the analyzed DH BRCA1/2 families, the most frequent was OC $(21.4 \%)$, followed by BC, prostate cancer (PC), and CC, with a percentage of $14.3 \%$, and bBC, breast and ovarian cancer (BOC), bladder cancer (BLC), leukemia (LEU), and laryngeal cancer (LAC), with a percentage of $7.1 \%$ (Figure 6). In a recent study, BRCA1/2 mutation carriers displayed an increased risk for PC (3.4-fold increased risk in BRCA1, 8.6-fold increased risk in BRCA2) [51]. Moreover, the BRCA2 mutations carriers have greater risk of bile duct, gall bladder, pancreatic, gastro-intestinal tumors, and melanoma [52], while the BRCA1 mutations carriers of CC [53].

About the age of cancer development in the DH carriers, the occurrence of the first cancer should be earlier than in the carriers of a single $B R C A$ mutation [7]. However, data about the younger age of $\mathrm{DH}$ carriers in $\mathrm{BC}$ development are conflicting. As described above, data concerning the $B R C A$ $\mathrm{DH}$ incidence in non-Ashkenazi and in Italian populations are few, and often they have documented single patients rather than family studies. Claus reported $\mathrm{DH}$ in a female affected with $\mathrm{BC}$ and diagnosed at an early age of 37 years [24]. Musolino described DH in a female with BC diagnosed at 
37 years [32]. Concolino reported DH in a female with bBC and age at diagnosis of 41 and 54 years [36]. Palmirotta reported that the median age at diagnosis for BC was 38 years, with a range of 26-76 [7]. In our patients, the mean age at $\mathrm{BC}$ diagnosis was 54.5 years (Table 5) but the range was $32-70$ years, in line with data reported by Palmirotta.

Among the tumors reported in DM $B R C A 2$ families, the most frequent was $\mathrm{BC}$, with a percentage of $76.2 \%$, followed by bBC, male breast cancer (MBC), CC, pancreatic cancer (PAC), and LEU with a percentage of $4.8 \%$ (Figure 6). The tumors recurring in the families with DM are the same as in the carriers of $B R C A 2$ single mutations. Particularly, $B R C A 2$ mutations are found in up to $2 \%$ of PAC cases [54]. The BRCA2 DM c.631G >A (p.Val211Ile)/c.7008-2A >T (IVS13-2A >T) was previously reported in a patient with PAC [40]. Accordingly, in family 5 with DM a case of PAC was reported, but the genetic test could not be assessed since the patient died. This data supports the hypothesis of a correlation between $B R C A 2$ and PAC. In relation to the age of cancer onset, in DM patient with PAC we did not observe a younger age compared with carriers of a single BRCA2 mutation [55].

Overall, the literature data indicate that $\mathrm{DH}$, although rare, is more frequently reported than $\mathrm{DM}$ (Tables 6 and 7). Otherwise, our analysis shows a higher frequency of DM $(0.5 \%)$ than DH $(0.3 \%)$, in accordance with the data of Concolino, reporting a highest DM frequency (1.6\%) compared to $\mathrm{DH}(0.8 \%)$ [36]. This different result could be due to the small number of samples tested in these two studies.

Analyzing the types of tumors occurring in families with DH and DM (see Figure 6), we observed $\mathrm{OC}$ and BOC only in families with DH but not with DM. This finding could be due to the presence of $B R C A 1$ mutations in $\mathrm{DH}$ cases; indeed, it is recognized that these mutations highly predispose to the OC onset. Likewise, an increased risk of OC in patients with BRCA1/2 DH compared to BRCA2 mutation carriers was found [8]. Furthermore, MBC was present in families with DM, whereas no cases were diagnosed in $\mathrm{DH}$ families, thus confirming that $B R C A 2$ mutations have a greater penetrance BC development in men [56]. Similarly, PAC was reported in families with DM but not with DH, further supporting the notion that $B R C A 2$ mutations are associated with an increased risk of PAC [57].

About the age of onset of various cancer types, we did not observe significant differences between families with DH and DM. The only discrepancy concerns CC (Table 5), which could have an earlier onset in families with $\mathrm{DH}$, probably due to the presence of $B R C A 1$ in $\mathrm{DH}$; indeed, a greater risk of $\mathrm{CC}$ at the age of about 50 years in $B R C A 1$ mutation carriers was reported [58].

In addition to $B R C A$ genes, $\mathrm{DH}$ can also involve other cancer susceptibility genes. To date, we have shown patients with DH in BRCA2/MSH2, BRCA2/APC, BRCA1/MSH6, BRCA1/MLH1, BRCA1/ATM, $B R C A 1 / C H E K 2, B R C A 1 / B L M$, and BRCA1/APC [59-63].

\section{Conclusions}

The detection of DH could have important clinical implications for the management of patients and for risk assessment in the family members of mutated patients. In order to identify all possible cases of $\mathrm{DH}$ in genes of high and moderate penetrance for cancer, a genetic test based on multiple genes involved in tumor predisposition syndromes is essential.

Author Contributions: Conceptualization, M.T.V. and M.R.; methodology, G.C. and G.D.; validation, G.D. and C.D.I.; investigation, G.C. and G.D.; resources, A.M.M.; data curation, G.D. and P.B.M.; writing-original draft preparation, M.R. and G.D.; writing-review and editing, M.T.V., A.M.M., and A.C.; visualization, M.R. and G.D.; supervision, A.C., M.C., M.T.V., and A.M.M. All authors have read and agreed to the published version of the manuscript.

Funding: This research received no external funding.

Conflicts of Interest: The authors declare no conflict of interest. 


\section{References}

1. Rebbeck, T.R.; Friebel, T.M.; Friedman, E.; Hamann, U.; Huo, D.; Kwong, A.; Olah, E.; Olopade, O.I.; Solano, A.R.; Teo, S.H.; et al. Mutational spectrum in a worldwide study of 29,700 families with BRCA1 or BRCA2 mutations. J. Clin. Oncol. 2018, 36, 414-424. [CrossRef] [PubMed]

2. Palmero, E.I.; Carraro, D.M.; Alemar, B.; Moreira, M.A.M.; Ribeiro-Dos-Santos, Â.; Abe-Sandes, K.; Galvão, H.C.R.; Reis, R.M.; de Pádua Souza, C.; Campacci, N.; et al. The germline mutational land-scape of BRCA1 and BRCA2 in Brazil. Sci. Rep. 2018, 8, 9188. [CrossRef] [PubMed]

3. Riedlova, P.; Janoutova, J.; Hermanova, B. Frequency of mutations in BRCA genes and other candidate genes in high-risk probands or probands with breast or ovarian cancer in the Czech Republic. Mol. Biol. Rep. 2020, 47, 2763-2769. [CrossRef] [PubMed]

4. Maiorino, M.I.; Schisano, B.; Di Palo, C.; Vietri, M.T.; Cioffi, M.; Giugliano, G.; Giugliano, D.; Esposito, K. Interleukin-20 circulating levels in obese women: Effect of weight loss. Nutr. Metab. Cardiovasc. Dis. 2010, 20, 180-185. [CrossRef] [PubMed]

5. Ossa, C.A.; Torres, D. Founder and Recurrent Mutations in BRCA1 and BRCA2 Genes in Latin American Countries: State of the Art and Literature Review. Oncologist 2016, 21, 832-839. [CrossRef] [PubMed]

6. Li, A.; Xie, R.; Zhi, Q.; Deng, Y.; Wu, Y.; Li, W.; Yang, L.; Jiao, Z.; Luo, J.; Zi, Y.; et al. BRCA germline mutations in an unselected nationwide cohort of Chinese patients with ovarian cancer and healthy controls. Gynecol. Oncol. 2018, 151, 145-152. [CrossRef] [PubMed]

7. Palmirotta, R.; Lovero, D.; Stucci, L.S.; Silvestris, E.; Quaresmini, D.; Cardascia, A.; Silvestris, F. Double Heterozygosity for BRCA1 Pathogenic Variant and BRCA2 Polymorphic Stop Codon K3326X: A Case Report in a Southern Italian Family. Int. J. Mol. Sci. 2018, 19, 285. [CrossRef]

8. Le Page, C.; Rahimi, K.; Rodrigues, M.; Heinzelmann-Schwarz, V.; Recio, N.; Tommasi, S.; Bataillon, G.; Portelance, L.; Golmard, L.; Meunier, L.; et al. Clinicopathological features of women with epithelial ovarian cancer and double heterozygosity for BRCA1 and BRCA2: A systematic review and case report analysis. Gynecol. Oncol. 2020, 156, 377-386. [CrossRef]

9. Ramus, S.J.; Friedman, L.S.; Gayther, S.A.; Ponder, B.A.; Bobrow, L.; van der Looji, M.; Papp, J.; Olah, E. A breast/ovarian cancer patient with germline mutations in both BRCA1 and BRCA2. Nat. Genet. 1997, 15, 14-15. [CrossRef]

10. Gershoni-Baruch, R.; Dagan, E.; Kepten, I.; Freid, G. Co-segregation of BRCA1 185delAG mutation and BRCA2 6174delT in one single family. Eur. J. Cancer 1997, 33, 2283-2284. [CrossRef]

11. Friedman, E.; Bar-Sade Bruchim, R.; Kruglikova, A.; Risel, S.; Levy-Lahad, E.; Halle, D.; Bar-On, E.; Gershoni-Baruch, R.; Dagan, E.; Kepten, I.; et al. Double heterozygotes for the Ashkenazi founder mutations in BRCA1 and BRCA2 genes. Am. J. Hum. Genet. 1998, 63, 1224-1227. [CrossRef] [PubMed]

12. Moslehi, R.; Russo, D.; Phelan, C.; Jack, E.; Antman, K.; Narod, S. An unaffected individual from a breast/ovarian cancer family with germline mutations in both BRCA1 and BRCA2. Clin. Genet. 2000, 57, 70-73. [CrossRef] [PubMed]

13. Leegte, B.; van der Hout, A.H.; Deffenbaugh, A.M.; Bakker, M.K.; Mulder, I.M.; ten Berge, A.; Leenders, E.P.; Wesseling, J.; de Hullu, J.; Hoogerbrugge, N.; et al. Phenotypic expression of double heterozygosity for BRCA1 and BRCA2 germline mutations. J. Med. Genet. 2005, 42, e20. [CrossRef] [PubMed]

14. Lavie, O.; Narod, S.; Lejbkowicz, F.; Dishon, S.; Goldberg, Y.; Gemer, O.; Rennert, G. Double heterozygosity in the BRCA1 and BRCA2 genes in the Jewish population. Ann. Oncol. 2011, 22, 964-966. [CrossRef] [PubMed]

15. Bell, D.W.; Erban, J.; Sgroi, D.C.; Haber, D.A. Selective loss of heterozygosity in multiple breast cancers from a carrier of mutations in both BRCA1 and BRCA2. Cancer Res. 2002, 62, 2741-2743.

16. Spannuth, W.A.; Thaker, P.H.; Sood, A.K. Concomitant BRCA1 and BRCA2 gene mutations in an Ashkenazi Jewish woman with primary breast and ovarian cancer. Am. J. Obstet. Gynecol. 2007, 196, e6-e9. [CrossRef]

17. Randall, T.C.; Bell, K.A.; Rebane, B.A.; Rubin, S.C.; Boyd, J. Germline mutations of the BRCA1 and BRCA2 genes in a breast and ovarian cancer patient. Gynecol. Oncol. 1998, 70, 432-434. [CrossRef]

18. Tesoriero, A.; Andersen, C.; Southey, M.; Somers, G.; McKay, M.; Armes, J.; McCredie, M.; Giles, G.; Hopper, J.L.; Venter, D. De novo BRCA1 mutation in a patient with breast cancer and an inherited BRCA2 mutation. Am. J. Hum. Genet. 1999, 65, 567-569. [CrossRef] 
19. Heidemann, S.; Fischer, C.; Engel, C.; Fischer, B.; Harder, L.; Schlegelberger, B.; Niederacher, D.; Goecke, T.O.; Doelken, S.C.; Dikow, N.; et al. Double heterozygosity for mutations in BRCA1 and BRCA2 in German breast cancer patients: Implications on test strategies and clinical management. Breast Cancer Res. Treat. 2012, 134, 1229-1239. [CrossRef]

20. Liede, A.; Rehal, P.; Vesprini, D.; Jack, E.; Abrahamson, J.; Narod, S.A. A breast cancer patient of Scottish descent with germ-line mutations in BRCA1 and BRCA2. Am. J. Hum. Genet. 1998, 62, 1543-1544. [CrossRef]

21. Loader, S.; Rowley, P.T. Deleterious mutations of both BRCA1 and BRCA2 in three siblings. Genet. Test. 1998, 2, 75-77. [CrossRef] [PubMed]

22. Caldes, T.; de la Hoya, M.; Tosar, A.; Sulleiro, S.; Godino, J.; Ibañez, D.; Martin, M.; Perez-Segura, P.; Diaz-Rubio, E. A breast cancer family from Spain with germline mutations in both the BRCA1 and BRCA2 genes. J. Med. Genet. 2002, 39, e44. [CrossRef]

23. Choi, D.H.; Lee, M.H.; Bale, A.E.; Carter, D.; Haffty, B.G. Incidence of BRCA1 and BRCA2 mutations in young Korean breast cancer patients. J. Clin. Oncol. 2004, 22, 1638-1645. [CrossRef] [PubMed]

24. Claus, E.B.; Petruzella, S.; Matloff, E.; Carter, D. Prevalence of BRCA1 and BRCA2 mutations in women diagnosed with ductal carcinoma in situ. JAMA 2005, 293, 964-969. [CrossRef]

25. Smith, M.; Fawcett, S.; Sigalas, E.; Bell, R.; Devery, S.; Andrieska, N.; Winship, I. Familial breast cancer: Double heterozygosity for BRCA1 and BRCA2 mutations with differing phenotypes. Fam. Cancer 2008, 7, 119-124. [CrossRef] [PubMed]

26. Steffensen, A.Y.; Jønson, L.; Ejlertsen, B.; Gerdes, A.M.; Nielsen, F.C.; Hansen, T.V. Identification of a Danish breast/ovarian cancer family double heterozygote for BRCA1 and BRCA2 mutations. Fam. Cancer 2010, 9, 283-287. [CrossRef] [PubMed]

27. Augustyn, A.M.; Agostino, N.M.; Namey, T.L.; Nair, S.; Martino, M.A. Two patients with germline mutations in both BRCA1 and BRCA2 discovered unintentionally: A case series and discussion of BRCA testing modalities. Breast Cancer Res. Treat. 2011, 129, 629-634. [CrossRef]

28. Noh, J.M.; Choi, D.H.; Nam, S.J.; Lee, J.E.; Kim, J.W.; Kim, S.W.; Kang, E.; Lee, M.H.; Ahn, S.H.; Kim, K.S.; et al. Characteristics of double heterozygosity for BRCA1 and BRCA2 germline mutations in Korean breast cancer patients. Breast Cancer Res. Treat. 2012, 131, 217-222. [CrossRef] [PubMed]

29. Loubser, F.; de Villiers, J.N.; van der Merwe, N.C. Two double heterozygotes in a South African Afrikaner family: Implications for BRCA1 and BRCA2 predictive testing. Clin. Genet. 2012, 82, 599-600. [CrossRef]

30. Nomizu, T.; Matsuzaki, M.; Katagata, N.; Kobayashi, Y.; Sakuma, T.; Monma, T.; Saito, M.; Watanabe, F.; Midorikawa, S.; Yamaguchi, Y. A case of familial breast cancer with double heterozygosity for BRCA1 and BRCA2 genes. Breast Cancer 2015, 22, 557-561. [CrossRef]

31. Meynard, G.; Mansi, L.; Lebahar, P.; Villanueva, C.; Klajer, E.; Calcagno, F.; Vivalta, A.; Chaix, M.; Collonge-Rame, M.A.; Populaire, C.; et al. First description of a double heterozygosity for BRCA1 and BRCA2 pathogenic variants in a French metastatic breast cancer patient: A case report. Oncol. Rep. 2017, 37, 1573-1578. [CrossRef]

32. Musolino, A.; Naldi, N.; Michiara, M.; Bella, M.A.; Zanelli, P.; Bortesi, B.; Capelletti, M.; Savi, M.; Neri, T.M.; Ardizzoni, A. A breast cancer patient from Italy with germline mutations in both the BRCA1 and BRCA2 genes. Breast Cancer Res. Treat. 2005, 91, 203-205. [CrossRef] [PubMed]

33. Pilato, B.; De Summa, S.; Danza, K.; Lambo, R.; Paradiso, A.; Tommasi, S. Maternal and paternal lineage double heterozygosity alteration in familial breast cancer: A first case report. Breast Cancer Res. Treat. 2010, 124, 875-878. [CrossRef] [PubMed]

34. Zuradelli, M.; Peissel, B.; Manoukian, S.; Zaffaroni, D.; Barile, M.; Pensotti, V.; Cavallari, U.; Masci, G.; Mariette, F.; Benski, A.C.; et al. Four new cases of double heterozygosity for BRCA1 and BRCA2 gene mutations: Clinical, pathological, and family characteristics. Breast Cancer Res. Treat. 2010, 124, 251-258. [CrossRef] [PubMed]

35. Vietri, M.T.; Molinari, A.M.; Caliendo, G.; De Paola, M.L.; D’Elia, G.; Gambardella, A.L.; Petronella, P.; Cioffi, M. Double heterozygosity in the BRCA1 and BRCA2 genes in Italian family. Clin. Chem. Lab. Med. 2013, 51, 2319-2324. [CrossRef] [PubMed]

36. Concolino, P.; Gelli, G.; Rizza, R.; Costella, A.; Scambia, G.; Capoluongo, E. BRCA1 and BRCA2 Testing through Next Generation Sequencing in a Small Cohort of Italian Breast/Ovarian Cancer Patients: Novel Pathogenic and Unknown Clinical Significance Variants. Int. J. Mol. Sci. 2019, 20, 3442. [CrossRef] 
37. Pensabene, M.; Spagnoletti, I.; Capuano, I.; Condello, C.; Pepe, S.; Contegiacomo, A.; Lombardi, G.; Bevilacqua, G.; Caligo, M.A. Two mutations of BRCA2 gene at exon and splicing site in a woman who underwent oncogenetic counseling. Ann. Oncol. 2009, 20, 874-878. [CrossRef]

38. Vietri, M.T.; Caliendo, G.; D’Elia, G.; Resse, M.; Casamassimi, A.; Minucci, P.B.; Cioffi, M.; Molinari, A.M. $B R C A$ and PALB2 mutations in a cohort of male breast cancer with one bilateral case. Eur. J. Med. Genet. 2020, 63, 103883. [CrossRef]

39. Colombo, M.; Ripamonti, C.B.; Pensotti, V.; Foglia, C.; Peissel, B.; Pierotti, M.A.; Manoukian, S.; Radice, P. An unusual BRCA2 allele carrying two splice site mutations. Ann. Oncol. 2009, 20, 1143-1144. [CrossRef]

40. Lowery, M.A.; Kelsen, D.P.; Stadler, Z.K.; Yu, K.H.; Janjigian, Y.Y.; Ludwig, E.; D' Adamo, D.R.; Salo-Mullen, E.; Robson, M.E.; Allen, P.J.; et al. An emerging entity: Pancreatic adenocarcinoma associated with a known BRCA mutation: Clinical descriptors, treatment implications, and future directions. Oncologist. 2011, 16, 1397-1402. [CrossRef]

41. Wallace, A.J. New challenges for BRCA testing: A view from the diagnostic laboratory. Eur. J. Hum. Genet. 2016, 24 (Suppl. 1), S10-S18. [CrossRef] [PubMed]

42. Vietri, M.T.; Molinari, A.M.; De Paola, M.L.; Cantile, F.; Fasano, M.; Cioffi, M. Identification of a novel in-frame deletion in $B R C A 2$ and analysis of variants of $B R C A 1 / 2$ in Italian patients affected with hereditary breast and ovarian cancer. Clin. Chem. Lab. Med. 2012, 50, 2171-2180. [CrossRef] [PubMed]

43. ClinVar Database. Available online: https://www.ncbi.nlm.nih.gov/clinvar/variation/ (accessed on 4 June 2020).

44. Rebbeck, T.R.; Friebel, T.M.; Mitra, N.; Wan, F.; Chen, S.; Andrulis, I.L.; Apostolou, P.; Arnold, N.; Arun, B.K.; Barrowdale, D.; et al. Inheritance of deleterious mutations at both BRCA1 and BRCA2 in an international sample of 32,295 women. Breast Cancer Res. 2016, 18, 112. [CrossRef] [PubMed]

45. Frank, T.S.; Deffenbaugh, A.M.; Reid, J.E.; Hulick, M.; Ward, B.E.; Lingenfelter, B.; Gumpper, K.L.; Scholl, T.; Tavtigian, S.V.; Pruss, D.R.; et al. Clinical characteristics of individuals with germline mutations in BRCA1 and BRCA2: Analysis of 10,000 individuals. J. Clin. Oncol. 2002, 20, 1480-1490. [CrossRef]

46. Zhang, S.; Royer, R.; Li, S.; McLaughlin, J.R.; Rosen, B.; Risch, H.A.; Fan, I.; Bradley, L.; Shaw, P.A.; Narod, S.A. Frequencies of $B R C A 1$ and $B R C A 2$ mutations among 1342 unselected patients with invasive ovarian cancer. Gynecol. Oncol. 2011, 121, 353-357. [CrossRef]

47. Borg, A.; Haile, R.W.; Malone, K.E.; Capanu, M.; Diep, A.; Törngren, T.; Teraoka, S.; Begg, C.B.; Thomas, D.C.; Concannon, P.; et al. Characterization of BRCA1 and BRCA2 deleterious mutations and variants of unknown clinical significance in unilateral and bilateral breast cancer: The WECARE study. Hum. Mutat. 2010, 31, E1200-E1240. [CrossRef] [PubMed]

48. Minucci, A.; De Bonis, M.; Costella, A.; Scambia, G.; Scandurra, G.; Capoluongo, E. Multidisciplinary team for elucidation of any new mutation and how this approach can be useful to individualize any genetic result: The case of BRCA2 c.631G>A/c.7008-2A>T genotype. Response to: Nagy PL, Mansukhani M. The role of clinical genomic testing in diagnosis and discovery of pathogenic mutations. Expert Rev Mol Diagn 2015;15(9):1101-5. Expert Rev. Mol. Diagn. 2016, 16, 715-717. [CrossRef]

49. Niraj, J.; Färkkilä, A.; D’Andrea, A.D. The Fanconi Anemia Pathway in Cancer. Annu Rev Cancer Biol. 2019, 3, 457-478. [CrossRef]

50. Gaildrat, P.; Krieger, S.; Di Giacomo, D.; Abdat, J.; Révillion, F.; Caputo, S.; Vaur, D.; Jamard, E.; Bohers, E.; Ledemeney, D.; et al. Multiple sequence variants of BRCA2 exon 7 alter splicing regulation. J. Med. Genet. 2012, 49, 609-617. [CrossRef]

51. Toss, A.; Venturelli, M.; Molinaro, E.; Pipitone, S.; Barbieri, E.; Marchi, I.; Tenedini, E.; Artuso, L.; Castellano, S.; Marino, M.; et al. Hereditary Pancreatic Cancer: A Retrospective Single-Center Study of 5143 Italian Families with History of BRCA-Related Malignancies. Cancers 2019, 11, 193. [CrossRef]

52. Shailani, A.; Kaur, R.P.; Munshi, A. A comprehensive analysis of BRCA2 gene: Focus on mechanistic aspects of its functions, spectrum of deleterious mutations, and therapeutic strategies targeting BRCA2-deficient tumors. Med. Oncol. 2018, 35, 18. [CrossRef]

53. Varol, U.; Kucukzeybek, Y.; Alacacioglu, A.; Somali, I.; Altun, Z.; Aktas, S.; Oktay Tarhan, M. BRCA genes: BRCA 1 and BRCA 2. J. BUON 2018, 23, 862-866. [PubMed]

54. Pilarski, R. The Role of BRCA Testing in Hereditary Pancreatic and Prostate Cancer Families. Am. Soc. Clin. Oncol. Educ. Book 2019, 39, 79-86. [CrossRef] [PubMed] 
55. Couch, F.J.; Johnson, M.R.; Rabe, K.G.; Brune, K.; de Andrade, M.; Goggins, M.; Rothenmund, H.; Gallinger, S.; Klein, A.; Petersen, G.M.; et al. The prevalence of BRCA2 mutations in familial pancreatic cancer. Cancer Epidemiol. Biomarkers Prev. 2007, 16, 342-346. [CrossRef] [PubMed]

56. Scarpitta, R.; Zanna, I.; Aretini, P.; Gambino, G.; Scatena, C.; Mei, B.; Ghilli, M.; Rossetti, E.; Roncella, M.; Congregati, $\mathrm{C}$; et al. Germline investigation in male breast cancer of DNA repair genes by next-generation sequencing. Breast Cancer Res. Treat. 2019, 178, 557-564. [CrossRef]

57. Mersch, J.; Jackson, M.; Park, M.; Nebgen, D.; Peterson, S.K.; Singletary, C.; Arun, B.K.; Litton, J.K. Cancers associated with BRCA1 and BRCA2 mutations other than breast and ovarian. Cancer 2015, 121, 269-275. [CrossRef]

58. Lee, M.V.; Katabathina, V.S.; Bowerson, M.L.; Mityul, M.I.; Shetty, A.S.; Elsayes, K.M.; Balachandran, A.; Bhosale, P.R.; McCullough, A.E.; Menias, C.O. BRCA-associated Cancers: Role of Imaging in Screening, Diagnosis, and Management. Radiographics 2017, 37, 1005-1023. [CrossRef]

59. Sokolenko, A.P.; Bogdanova, N.; Kluzniak, W.; Preobrazhenskaya, E.V.; Kuligina, E.S.; Iyevleva, A.G.; Aleksakhina, S.N.; Mitiushkina, N.V.; Gorodnova, T.V.; Bessonov, A.A.; et al. Double heterozygotes among breast cancer patients analyzed for BRCA1,CHEK2, ATM, NBN/NBS1, and BLM germ-line mutations. Breast Cancer Res. Treat. 2014, 145, 553-562. [CrossRef]

60. Njoroge, S.W.; Burgess, K.R.; Cobleigh, M.A.; Alnajar, H.H.; Gattuso, P.; Usha, L. Hereditary diffuse gastric cancer and lynch syndromes in a BRCA1/2 negative breast cancer patient. Breast Cancer Res. Treat. 2017, 166, 315-319. [CrossRef]

61. Goehringer, C.; Sutter, C.; Kloor, M.; Gebert, J.; Slater, E.P.; Keller, M.; Treiber, I.; Ganschow, P.; Kadmon, M.; Moog, U. Double germline mutations in APC and BRCA2 in an individual with a pancreatic tumor. Fam. Cancer 2017, 16, 303-309. [CrossRef]

62. Andrés, R.; Menao, S.; Arruebo, M.; Quílez, E.; Cardiel, M.J. Double heterozygous mutation in the BRCA1 and ATM genes involved in development of primary metachronous tumours: A case report. Breast Cancer Res. Treat. 2019, 177, 767-770. [CrossRef] [PubMed]

63. Vietri, M.T.; D’Elia, G.; Caliendo, G.; Casamassimi, A.; Resse, M.; Passariello, L.; Cioffi, M.; Molinari, A.M. Double mutation of APC and BRCA1 in an Italian family. Cancer Genet. 2020, 244, 32-35. [CrossRef] [PubMed]

Publisher's Note: MDPI stays neutral with regard to jurisdictional claims in published maps and institutional affiliations.

(C) 2020 by the authors. Licensee MDPI, Basel, Switzerland. This article is an open access article distributed under the terms and conditions of the Creative Commons Attribution (CC BY) license (http://creativecommons.org/licenses/by/4.0/). 